\title{
Pemberdayaan Kewirausahaan Berbasis Teknologi Informasi Bagi Masyarakat Penyandang Disabilitas Di Gunung Kidul
}

\author{
Halim Budi Santoso ${ }^{1}$, Argo Wibowo ${ }^{2}$, Jong Jek Siang ${ }^{3}$, \\ Rosa Delima ${ }^{4}$, Antonius Rachmat Chrismanto ${ }^{5}$ \\ Universitas Kristen Duta Wacana \\ ${ }^{1}$ hbudi@staff.ukdw.ac.id \\ 2argo@staff.ukdw.ac.id \\ 3jjsiang@staff.ukdw.ac.id \\ ${ }^{4}$ rosadelima@staff.ukdw.ac.id \\ 5anton@ti.ukdw.ac.id
}

\begin{abstract}
Abstrak: Teknologi Informasi telah diterapkan di beberapa bidang, termasuk salah satunya adalah untuk mendukung kegiatan penjualan pembelian secara daring. Masyarakat Penyandang Disabilitas Mitra Sejahtera memiliki beberapa produk unggulan yang telah dijual secara lokal lokal di lingkungan masing - masing atau beberapa kota / kabupaten di sekitar Daerah Istimewa Yogyakarta. Pemanfaatan Teknologi Informasi untuk bidang pemasaran akan dapat membantu dalam memperluas pasar dan meningkatkan target konsumen. Akan tetapi, Masyarakat Penyandang Disabilitas Mitra Sejahtera belum memiliki akses dan kemampuan yang memadai untuk melakukan pembukaan toko secara online. Selain itu, pemanfaatan smartphone bagi anggota Masyarakat Penyandang Disabilitas Mitra Sejahtera juga belum optimal. Kegiatan pelatihan dan pengabdian kepada masyarakat ini diadakan untuk membantu anggota Penyandang Disabilitas Mitra Sejahtera untuk dapat memanfaatkan smartphone dengan sistem operasi Android. Kegiatan pelatihan dan pengabdian ini juga digunakan untuk memberikan pengetahuan kepada peserta terkait dengan penggunaan teknologi internet untuk membantu berjualan secara daring. Sebagai hasil dari kegiatan ini, halaman resmi media sosial terbentuk dan peserta juga membuat toko online di salah satu situs marketplace terbesar di Indonesia.
\end{abstract}

Kata kunci: Kewirausahaan, Teknologi Informasi, Masyarakat Penyandang Disabilitas, Kewirausahaan Berbasis Teknologi Informasi. Pemberdayaan Masyarakat.

\begin{abstract}
Information Technology has been implemented in some sectors in life. One of them is the usage of Information Technology for online commerce. Mitra Sejahtera Disabled Person Organization has some featured products which are sold locally in some places nearby and only in Gunung Kidul. The usage of Information Technology in marketing will help people to expand the basic consumer and market. On the other hand, Mitra Sejahtera Disabled Person Organization does not have enough access and ability to start and open online shop. Furthermore, the usage of the smartphone for member of Mitra Sejahtera Disabled Person Organization has not been optimal yet, like the utilization of social media as an official account.

Training and empowerment activities to Mitra Sejahtera Disabled Person Organization will contribute in increasing and optimizing the utilization of social media and e-commerce. This training and empowerment activities also will give some knowledge to the participant about how to open online shop in one of the biggest online marketplace in Indonesia. The result of this activity is official account in media social. The participant also encouraged and trained to start online shop in one of the biggest online marketplace platform in Indonesia.
\end{abstract}

Keywords: Entrepreneurship, Information Technology, Disabled Person Organization, Entrepreneurship based Technology, Community Empowerment 


\section{PENDAHULUAN}

Penyandang Disabilitas merupakan warga masyarakat yang memiliki hak dan kewajiban yang setara dengan masyarakat lainnya. Hal ini yang diperjuangkan oleh Pusat Pemberdayaan Disabilitas Mitra Sejahtera yang berada di Kecamatan Nglipar, Gunung Kidul. Organisasi ini memberikan beberapa ketrampilan dan pembekalan kepada anggotanya. Selain itu, Pusat Pemberdayaan Disabilitas juga menyediakan kegiatan advokasi, terutama di bidang kesehatan bagi penyandang disabilitas agar memiliki kemandirian dalam ekonomi dan kehidupan.

\section{Pusat Pemberdayaan Disabilitas} Mitra Sejahtera memiliki kantor sekretariat di kecamatan Nglipar, di gedung eks SMA Kartika VII. Pusat Pemberdayaan Disabilitas Mitra Sejahtera ini berdiri pada tahun 9 Mei 2012 dan telah memiliki anggota 25 orang, yang tersebar di lima desa dan dua kecamatan di Gunung Kidul.

Pusat Pemberdayaan Disabilitas Mitra Sejahtera terus melakukan investasi dalam pengembangan sumberdaya manusia, khususnya bagi anggota. Pusat Pemberdayaan Disabilitas Mitra Sejahtera memberikan beberapa kegiatan pelatihan, diantaranya pelatihan untuk meningkatkan kewirausahaan berbasis teknologi informasi.

Salah satu perkembangan yang sedang dilakukan oleh Pusat Pemberdayaan
Disabilitas Mitra Sejahtera adalah pengembangan kewirausahaan berbasis masyarakat atau yang lebih dikenal dengan socioenterpreneur. Socioenterpreneur merupakan salah satu pemanfaatan perilaku kewirausahaan yang berorientasi untuk pencapaian tujuan sosial dengan tidak mengutamakan perolehan laba, atau laba yang diperoleh dapat digunakan untuk kepentingan sosial (Utomo, 2014).

Peningkatan kewirausahaan berbasis sosial juga menjadi salah satu topik yang digunakan sebagai salah satu mata pelajaran yang digunakan dalam pembentukan mahasiswa (Rahmawaty, Suwarto, \& Endarwati, 2011) dan dapat membantu dalam mengatasi pengangguran, kemiskinan, dan kerusakan lingkungan (Palesangi, 2012).

Pengembangan kewirausahaan ini juga harus diikuti dengan peningkatan kemampuan dalam bidang Teknologi Informasi. Penggunaan promosi berbasis Teknologi Informasi tentunya akan sangat membantu memberikan pengaruh kepada masyarakat terkait dengan produk yang dimilikinya. Salah satu penggunaan teknologi informasi adalah, penggunaan media sosial yang membantu dalam menghubungkan banyak orang dengan mudah dan gratis (Purwidiantoro, S.W., \& Hadi, 2016).

Pemanfaatan media sosial berbasis internet juga dapat membantu Usaha Kecil dan Menengah (UKM) untuk dapat 
meningkatkan bekerjasama dengan pengusaha lainnya (Purwidiantoro, S.W., \& Hadi, 2016) dan dapat membantu dalam mengurangi biaya pemasaran (Handika, Maradona, \& Darma, 2018). Selain itu, Handika, Maradona, \& Darma (2018) juga menggunakan influencer untuk membantu dalam menarik konsumen yang sesuai dengan target pasar yang ada. Penggunaan influencer membantu dalam meningkatkan pemasaran di media sosial Instagram (Handika, Maradona, \& Darma, 2018).

Penggunaan media sosial sebagai salah satu sarana komunikasi pemasaran dapat dilakukan dengan penggunaan gambar, tulisan, dan beberapa post yang ada (Indika \& Jovita, 2017). Salah satu post yang paling disuka adalah komunikasi melalui foto atau gambar. Gambar atau foto yang diunggah ke dalam media sosial sangat membantu dalam meningkatkan minat beli konsumen dan memberikan korelasi yang positif terhadap minat beli tersebut (Indika \& Jovita, 2017).

Penggunaan Teknologi Informasi dan Komunikasi bagi Usaha Kecil dan Menengah (UKM) lainnya adalah penggunaan media eCommerce yang dapat digunakan sebagai sarana promosi. E-Commerce dapat meningkatkan volume penjualan, baik penjualan online maupun konvensional (Jauhari, 2010). Selain itu, penggunaan $e$ Commerce sebagai sarana jual beli produk UMKM juga dapat memperluas cakupan pasar, tidak mengenal ruang dan waktu, serta dapat dilakukan dimana saja dan kapan saja (Jauhari, 2010).

UKM diharapkan dapat meningkatkan kemampuan bersaingnya dengan para kompetitornya (Handayani, Saputro, Hidayanto, \& Budi, 2010) sehingga pemanfaatan Teknologi Informasi dan Komunikasi dapat meningkatkan produk UKM dalam menghadapi persaingan global, salah satunya adalah masyarakat ekonomi ASEAN (Ramadhani \& Arifin, 2013).

Pusat Pemberdayaan Disabilitas Mitra Sejahtera memiliki permasalah dalam penggunaan Teknologi Informasi dan Komunikasi (TIK) untuk membantu promosi dan mendukung kegiatan pemberdayaan kewirausahaan berbasis masyarakat tersebut. Oleh karena itu, program pelatihan disusun bersama dengan pengurus Pusat Pemberdayaan Disabilitas Mitra Sejahtera untuk pemanfaatan Teknologi Informasi dan Komunikasi dalam membantu meningkatkan pemasaran produk sehingga dapat memperluas sebaran produk anggota Mitra Sejahtera.

\section{RUMUSAN MASALAH}

Permasalahan yang dihadapi oleh Pusat Pemberdayaan Disabilitas Mitra Sejahtera adalah terkait dengan masih terbatasnya kemampuan anggota organisasi 
dalam memanfaatkan TIK untuk membantu memasarkan dan memperluas pasar hasil produk mereka, khususnya untuk keset jahit dan telur asin. Saat ini pemanfaatan teknologi masih digunakan sebatas untuk telekomunikasi pada umumnya seperti untuk mengirim pesan singkat dan telepon.

Permasalahan kedua yang dihadapi oleh anggota Pusat Pemberdayaan Disabilitas Mitra Sejahtera adalah anggota Pusat Pemberdayaan Disabilitas Mitra Sejahtera belum mengenal platform e-Commerce yang ada dan sering digunakan masyarakat. Produk yang ada selama ini dijual hanya ke orang sekitar yang letaknya berdekatan dengan rumah dari masing - masing anggota.

\section{METODE PELAKSANAAN}

Kegiatan pengabdian ini dilakukan bekerjasama dengan Pusat Pemberdayaan Disabilitas Mitra Sejahtera (PPDMS) yang berlokasi di Nglipar, Gunung Kidul, Daerah Istimewa Yogyakarta. Metode pelaksanaan meliputi aktifitas analisa terkait dengan kerangka pemecahan masalah, realisasi pemecahan masalah, penentuan target peserta, pelaksanaan kegiatan, dan evaluasi kegiatan. Metode ini pernah dilakukan untuk melakukan kegiatan pendampingan dan sosialisasi bagi masyarakat (Zain, Febriantara, \& Marsofiyati, 2017). Pendekatan kepada para peserta juga diperlukan untuk mengetahui terkait dengan penyampaian beberapa permasalahan yang dihadapi serta memberikan fakta dan contoh nyata (Zain, Febriantara, \& Marsofiyati, 2017).

\section{A. Kerangka Pemecahan Masalah}

Kegiatan pengabdian ini akan memiliki beberapa pemecahan masalah, yang diantaranya adalah untuk meningkatkan kapasitas dan kapabilitas dari peserta pengabdian untuk optimalisasi penggunaan smartphone Android. Selain itu, diharapkan kegiatan ini juga dapat membantu peserta pelatihan dalam menggunakan salah satu platform toko online yang ada di Indonesia.

Kegiatan pengabdian ini diharapkan juga menjadi salah satu sarana untuk meningkatkan kemampuan penggunaan teknologi internet dalam memasarkan produk hasil karya anggota Pusat Pemberdayaan Disabilitas Mitra Sejahtera.

Kegiatan pengabdian ini juga dilakukan untuk meningkatkan kemampuan peserta dalam menggunakan media social yang berupa halaman resmi dalam facebook dan Instagram. Halaman resmi ini nantinya diharapkan akan menjadi salah satu halaman bagi bisnis yang telah dikembangkan oleh peserta selama ini. Kegiatan pengabdian ini juga memberikan transfer pengetahuan kepada peserta pelatihan sehingga peserta pelatihan secara mandiri dapat melakukan aktivitas yang berkaitan dengan pemasaran produk hasil anggota mitra. 


\section{B. Realisasi Pemecahan Masalah}

Sesuai dengan kesepakatan pengurus Pusat Pemberdayaan Disabilitas Mitra Sejahtera, pelaksanaan kegiatan pelatihan dan pendampingan ini akan dilakukan pada tanggal 20 Juli 2019 dan 7 Agustus 2019. Pelatihan dilakukan selama 2 hari yang terpisah dikarenakan beberapa kesibukan yang ada di Pusat Pemberdayaan Disabilitas Mitra Sejahtera. Kegiatan akan dimulai pada pukul 09.00 dan diakhiri pada pukul 15.00.

\section{Penentuan Target Peserta}

Target peserta dari kegiatan pelatihan ini adalah anggota Pusat Pemberdayaan Disabilitas Mitra Sejahtera. Untuk mengikuti kegiatan ini, pengurus membagikan pesan kepada semua anggota Pusat Pemberdayaan Disabilitas Mitra Sejahtera melalui group Whatsapp. Apabila tertarik, peserta pelatihan dapat mendaftarkan dirinya kepada pengurus. Daftar peserta pelatihan dapat dilihat pada tabel I.

TABEL I

PESERTA PELATIHAN OPTIMALISASI ANDROID

\begin{tabular}{llll}
\hline No & $\begin{array}{c}\text { Organi } \\
\text { sasi }\end{array}$ & \multicolumn{1}{c}{ Nama } & \multicolumn{1}{c}{ Alamat } \\
\hline \hline \multirow{2}{*}{$\begin{array}{l}\text { Mitra } \\
\text { Sejahtera }\end{array}$} & $\begin{array}{l}\text { Lanjar } \\
\text { Risdiyaning } \\
\text { sih }\end{array}$ & $\begin{array}{l}\text { Kec. Nglipar, } \\
\text { Ds Nglipar, } \\
\text { Dsn Nglipar }\end{array}$ \\
\hline \multirow{2}{*}{ PKK } & Watini & $\begin{array}{l}\text { Kec. Nglipar, } \\
\text { Ds Nglipar, } \\
\text { Dsn Nglipar }\end{array}$ \\
\hline \multirow{3}{*}{3} & PKK & Arik & $\begin{array}{l}\text { Kec. Nglipar, } \\
\text { Ds Nglipar, } \\
\text { Dsn Nglipar }\end{array}$ \\
\hline
\end{tabular}

\begin{tabular}{|c|c|c|c|}
\hline 4 & $\begin{array}{l}\text { Mitra } \\
\text { Sejahtera }\end{array}$ & Dwi Sari & $\begin{array}{l}\text { Kec. Nglipar, } \\
\text { Ds Nglipar, } \\
\text { Dsn Mengger } \\
\end{array}$ \\
\hline 5 & $\begin{array}{l}\text { Mitra } \\
\text { Sejahtera }\end{array}$ & Sulastri & $\begin{array}{l}\text { Kec. Nglipar, } \\
\text { Ds Kedungpoh, } \\
\text { Dsn Gojo }\end{array}$ \\
\hline 6 & $\begin{array}{l}\text { Sedyo } \\
\text { Maju }\end{array}$ & $\begin{array}{l}\text { Eddy } \\
\text { Setiawan }\end{array}$ & $\begin{array}{l}\text { Kec.Karangmojo } \\
\text { Ds Jatiayu, } \\
\text { Dsn Pengkol } 3\end{array}$ \\
\hline 7 & $\begin{array}{l}\text { Mitra } \\
\text { Mandiri }\end{array}$ & Susanto & $\begin{array}{l}\text { Kec. Nglipar, } \\
\text { Ds Kedungpoh, } \\
\text { Dsn Nglorog }\end{array}$ \\
\hline 8 & $\begin{array}{l}\text { Mitra } \\
\text { Sejahtera }\end{array}$ & $\begin{array}{l}\text { Sigit } \\
\text { Prabowo }\end{array}$ & $\begin{array}{l}\text { Kec. Nglipar, } \\
\text { Ds Nglipar, } \\
\text { Dsn Mengger }\end{array}$ \\
\hline 9 & $\begin{array}{l}\text { Mitra } \\
\text { Sejahtera }\end{array}$ & Budi Yanto & $\begin{array}{l}\text { Kec. Nglipar, } \\
\text { Ds Nglipar, } \\
\text { Dsn Ngaliyan }\end{array}$ \\
\hline 10 & $\begin{array}{l}\text { Mitra } \\
\text { Mandiri }\end{array}$ & Paniyem & $\begin{array}{l}\text { Kec. Nglipar, } \\
\text { Ds Kedungpoh, } \\
\text { Dsn Kedungpoh } \\
\text { Lor }\end{array}$ \\
\hline 11 & $\begin{array}{l}\text { Mitra } \\
\text { Sejahtera }\end{array}$ & $\begin{array}{l}\text { Andi Joko } \\
\text { Prasetyo }\end{array}$ & $\begin{array}{l}\text { Kec. Nglipar, } \\
\text { Ds Nglipar, } \\
\text { Dsn Mengger }\end{array}$ \\
\hline 12 & $\begin{array}{l}\text { Mitra } \\
\text { Ananda }\end{array}$ & $\begin{array}{l}\text { Esti } \\
\text { Kristiyana }\end{array}$ & $\begin{array}{l}\text { Kec. Patuk, } \\
\text { Ds Patuk, } \\
\text { Dsn Ngandong }\end{array}$ \\
\hline
\end{tabular}

\section{Metode Pelaksanaan Kegiatan}

Kegiatan pengabdian disepakati untuk diadakan di Sekretariat Pusat Pemberdayaan Disabilitas Mitra Sejahtera yang beralamat di Jl. Nglipar - Wonosari, Kecamatan Nglipar, Gunung Kidul. Kegiatan pengabdian ini akan menggunakan metode 1) penjelasan, 2) sharing, 3) tanya jawab, 4) praktek untuk membuat halaman resmi untuk media social facebook dan instagram, 5) praktek membuka toko online di salah satu platform toko online yang ada di Indonesia, dan mengunggah barang dagangan di toko online tersebut, dan 6) pengukuran kemampuan peserta melalui pretest dan posttest. 
Patria : Jurnal Pengabdian Kepada Masyarakat

ISSN : 2656-5455 (media online) Vol. 3 | No. 1 Maret 2021

Pretest akan diberikan kepada peserta sebelum kegiatan pelatihan dilakukan. Posttest akan diberikan kepada peserta sesudah kegiatan pelatihan di lakukan. Soal yang diberikan dalam pilihan ganda dengan jumlah soal 20 soal. Hanya jawaban benar saja yang akan dihitung. Di dalam mengerjakan soal pretest dan posttest, peserta akan diberikan waktu 15 menit untuk mengerjakan soal tersebut. Soal telah dipersiapakn sebelumnya oleh pemateri dan diberikan dalam bentuk tercetak.

Tabel II di bawah ini menunjukkan jadwal pelatihan peserta yang telah disepakati bersama dengan Pusat Pemberdayaan Disabilitas Mitra Sejahtera (PPDMS). Seperti yang telah di jelaskan pada bagian sebelumnya, kegiatan ini diadakan 2 hari mulai dari pukul 09.00 - 15.00 WIB. Materi yang diberikan pun beragam mulai dari pengenalan dasar android sampai pembukaan akun resmi di salah satu platform eCommerce.

TABEL II

JadWal Pelatihan Peserta

\begin{tabular}{|c|c|c|}
\hline No & Tanggal & Materi \\
\hline 1 & $\begin{array}{l}20 \text { Juli } \\
2019\end{array}$ & $\begin{array}{ll}-\quad & \text { Pengenalan dasar android } \\
\text { - } & \text { Pengenalan dasar aplikasi } \\
\text { G-Suite, seperti: Google } \\
\text { Maps, Google Mail, dan } \\
\text { Google Docs } \\
\text { - } \quad \text { Pengenalan Instagram } \\
\text { untuk bisnis } \\
\end{array}$ \\
\hline 2 & $\begin{array}{l}7 \text { Agustus } \\
2019\end{array}$ & $\begin{array}{l}\text { - Pengenalan dan } \\
\text { pendampingan pembuatan } \\
\text { halaman resmi facebook } \\
\text { untuk akun resmi }\end{array}$ \\
\hline
\end{tabular}

- Pengenalan dan pendampingan pembuatan akun e-Commerce

\section{HASIL PEMBAHASAN}

Gambar 1, 2, 3, dan 4 menunjukkan suasana kegiatan pelatihan. Pada pelatihan kedua tanggal 7 Agustus, jumlah peserta lebih sedikit, dikarenakan beberapa peserta tidak dapat mengikuti kegiatan pelatihan. Peserta tersebut mengikuti beberapa kegiatan lain yang diadakan dalam rangka persiapan Idul Adha dan peringatan HUT RI ke 74.

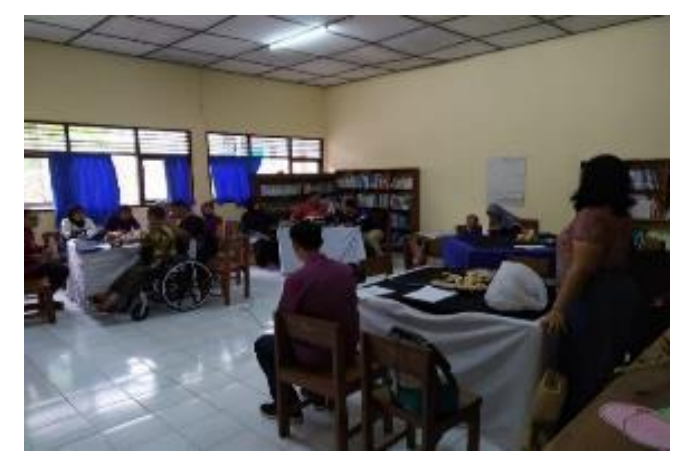

Gambar 1.Suasana Pelatihan 20 Juli 2019

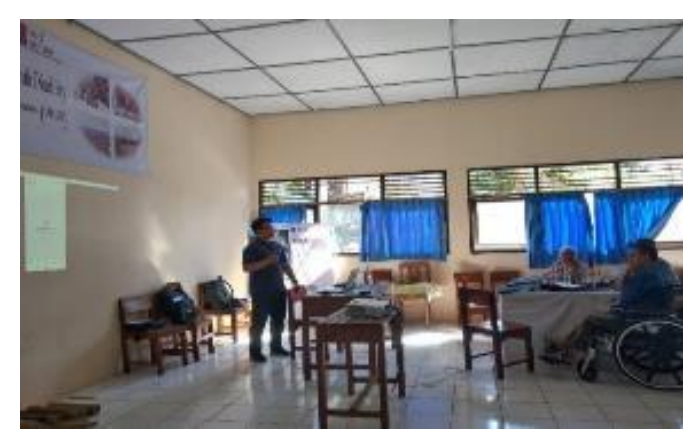

Gambar 2.Suasana Pelatihan 7 Agustus 2019 


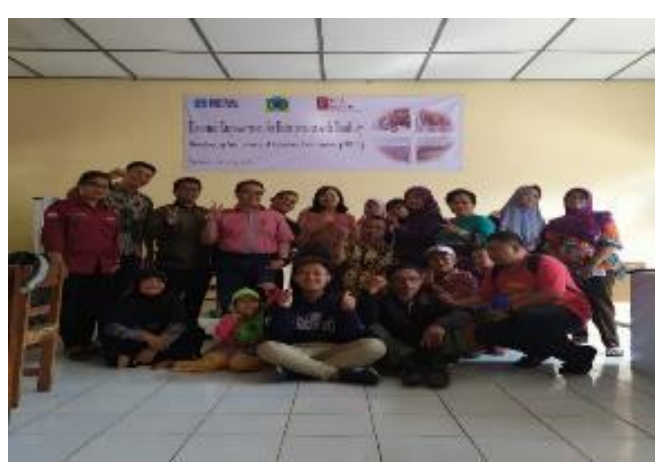

Gambar 3.Foto Bersama Peserta Pelatihan 20 Juli 2019

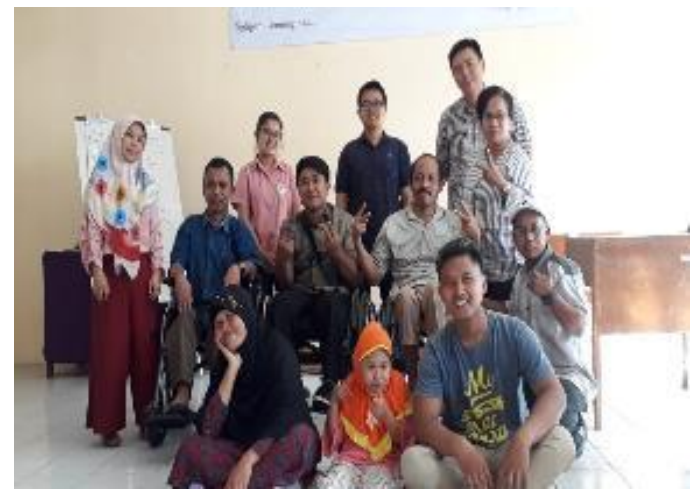

Gambar 4.Foto Bersama Peserta Pelatihan 7 Agustus 2019

Pelatihan sesi pertama yang melakukan pembahasan terkait dengan operasional android dasar. Peserta diberikan kesempatan untuk membuat akun google dan mengoptimalkan penggunaan calendar pada google calendar untuk membantu mengorganisasikan beberapa kegiatan yang ada di Pusat Pemberdayaan Disabilitas Mitra Sejahtera. Selain itu, di dalam kegiatan pelatihan ini, juga akan dilakukan pendampingan penggunaan halaman resmi facebook. Halaman resmi ini dapat berupa halaman resmi suatu organisasi, halaman resmi suatu produk, atau suatu kegiatan.

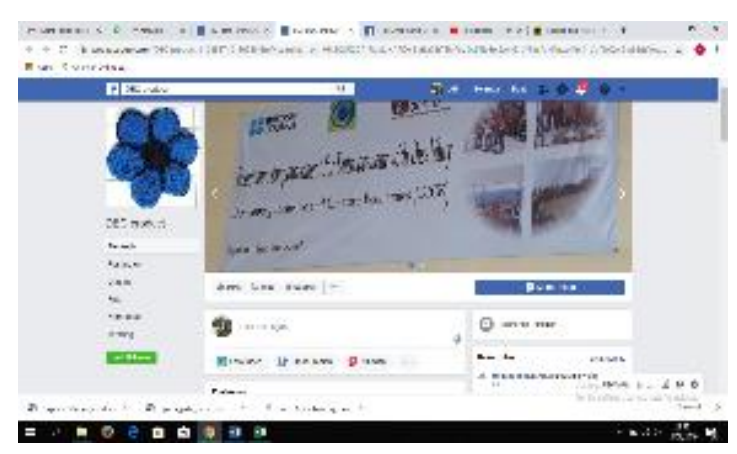

Gambar 5.Halaman Facebook Resmi DEC Product

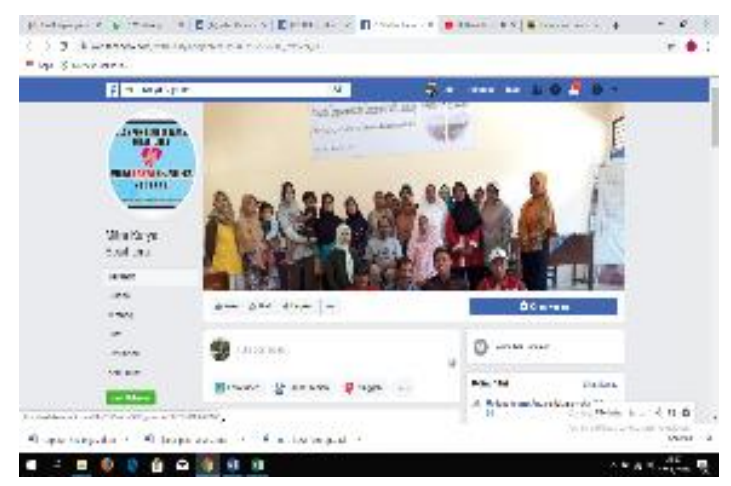

Gambar 6. Halaman Facebook Resmi Mitra Karya Sejahtera

Gambar 5 dan 6 menunjukkan halaman facebook resmi untuk Mitra Karya Sejahtera dan DEC Product. Halaman ini digunakan untuk menjadi halaman resmi dan memberikan informasi kepada para pengikut akun ini. Selain itu, akun ini nantinya akan digunakan juga untuk memberikan informasi untuk produk hasil dari Mitra Karya Sejahtera dan DEC Product, yaitu keset jahit. Setelah halaman facebook resmi yang dibuat pada pelatihan tersebut, selanjutnya pengguna membuat akun dan mulai berjualan di salah satu platform jual beli online, yaitu bukalapak Anggota Pusat Pemberdayaan Disabilitas Mitra Sejahtera memiliki beberapa produk unggulan, diantaranya telor 
Patria : Jurnal Pengabdian Kepada Masyarakat

ISSN : 2656-5455 (media online) Vol. 3 | No. 1 Maret 2021

asin dan kain perca jahit. Selain itu, masih terdapat beberapa produk lain seperti makanan ternak, ikan lele, produk herbal, dan produk makanan olahan lainnya.

Gambar 7 dan 8 menunjukkan gambar telor asin dan keset jahit hasil karya anggota Pusat Pemberdayaan Disabilitas Mitra Sejahtera (PPDMS). Produk - produk yang terdapat pada Gambar 7 dan 8 diatas menunjukkan produk - produk yang akan dijual melalui daring.

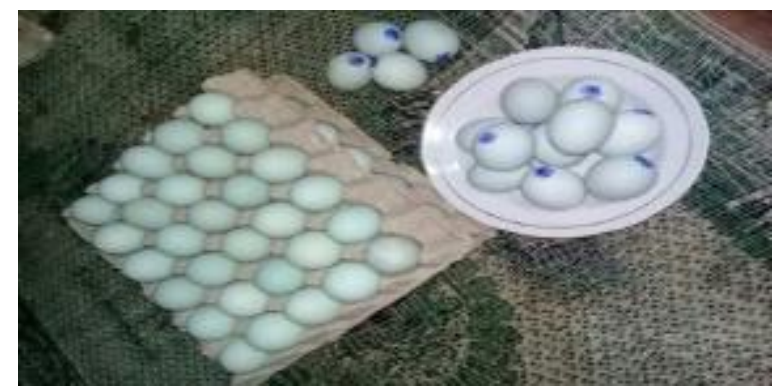

Gambar 7.Telor Asin Karya Anggota Pusat Pemberdayaan Disabilitas Mitra Sejahtera

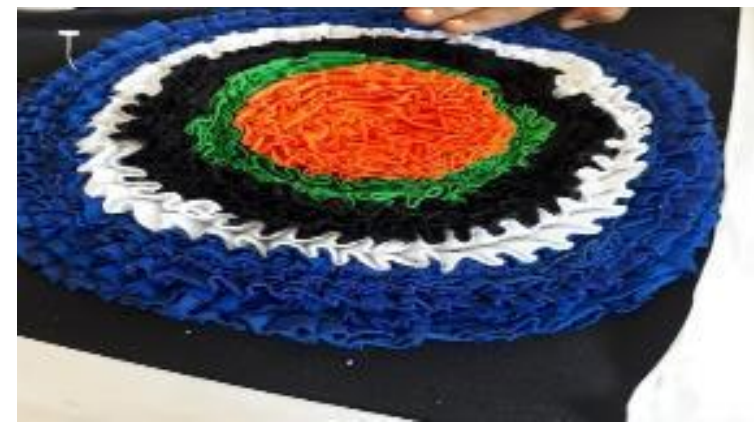

Gambar 8.Keset Jahit Hasil Karya Anggota

Pusat Pemberdayaan Disabilitas Mitra Sejahtera

Pada pelatihan kedua, peserta diberikan pembekalan dan pelatihan terkait dengan penggunaan smartphone Android, penggunaan media sosial untuk mendukung berjualan secara online, dan pembukaan toko online melalui platform e-Commerce yang telah ada. Peserta pelatihan terdiri dari masyarakat disabilitas yang merupakan anggota dari Pusat Pemberdayaan Disabilitas Mitra Sejahtera (PPDMS). Para peserta sebagian besar memiliki hasil karya yang akan dijual. Beberapa hasil karya yang dimiliki oleh peserta antara lain kesed dan telor asin. Gambar 9 dan 10 di bawah ini menunjukkan hasil akun bukalapak milik kedua peserta.

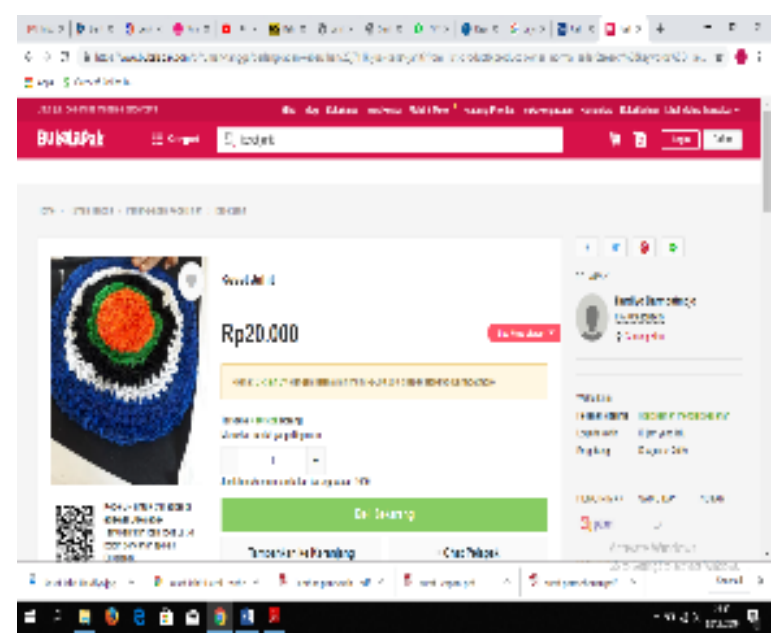

Gambar 9. Akun Hasil Pelatihan Jualan Online di salah satu platform e-Commerce berjualan Keset Jahit

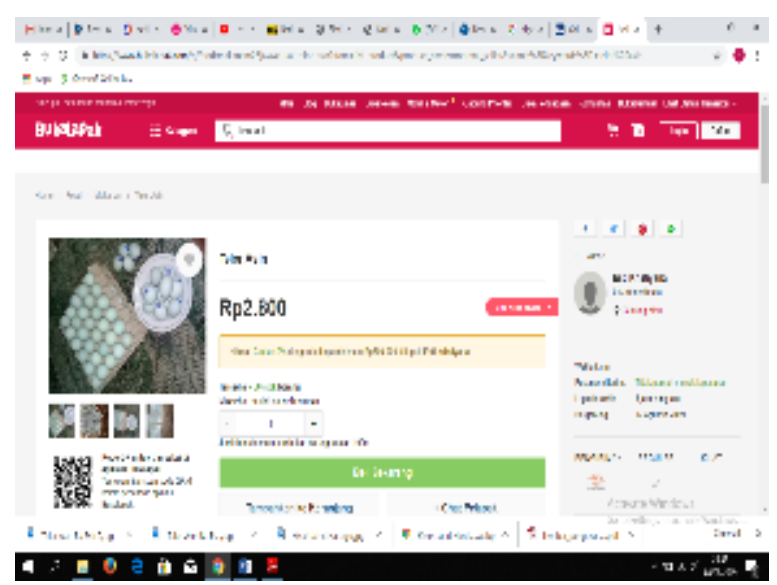


Gambar 10. Akun Hasil Pelatihan Jualan

Online di salah satu platform e-Commerce bejualan telor asin

Gambar 9 dan 10 menunjukkan akun bukalapak milik peserta pelatihan. Salah satu akun adalah milik ketua Pusat Pemberdayaan Disabilitas Mitra Sejahtera, Bpk. Hardiyo. Beliau berjualan keset jahit yang ada di halaman bukalapak dengan URL sebagai berikut:

https://www.bukalapak.com/p/rumahtangga/perlengkapan-kebersihan/23j711kjual-keset-jahit?from=list-

product\&product_owner=normal_seller\&sea $\underline{\text { rch\%5Bkeywords } \% 5 \mathrm{D}=\text { keset } \% 20 j a h i t}$.

Sedangkan untuk halaman yang menjual telor asin dapat dilihat pada akun berikut: https://www.bukalapak.com/p/food/makanan $\underline{23 j 4 \mathrm{vwc}-j u a l-t e l o r-a s i n ? f r o m=l i s t-}$

product\&product_owner=normal_seller\&sea rch\%5Bkeywords\%5D=telor\%20asin

Tim pengabdi juga melakukan pengukuran hasil pelatihan dengan mengadakan pretest dan posttest untuk materi pelatihan sesi kedua dengan tema Optimalisasi Penggunaan Smartphone Android ini. Hasil dari pretest dan posttest dapat dilihat pada tabel III di bawah ini:

TABEL IIII Hasil PRETEST DAN POSTTEST PESERTA PELATIHAN

\begin{tabular}{clcr}
\hline \multirow{2}{*}{ No } & \multirow{2}{*}{ Nama Peserta } & \multicolumn{2}{c}{ Pengukuran } \\
\cline { 3 - 4 } & & Pretest & Posttest \\
\hline 1 & Andi Joko & 16 & 16 \\
\hline 2 & Prasityo & 10 & 7 \\
\hline
\end{tabular}

\begin{tabular}{clcc}
\hline 3 & $\begin{array}{l}\text { Arik } \\
\text { Widaryanti }\end{array}$ & 9 & 14 \\
\hline 4 & Dwi Sari & 12 & 13 \\
\hline 5 & Sulastri & 9 & 13 \\
\hline 6 & Eddy Setiawan & 12 & 15 \\
\hline 7 & Esti Kristiyana & 10 & 11 \\
\hline 8 & Budiyanto & 13 & 14 \\
\hline 9 & Sigit Prabowo & 12 & 13 \\
\hline 10 & Lanjar & 11 & 15 \\
\hline 11 & Paniyem & 6 & 7 \\
\hline 12 & Mariman & 14 & 11 \\
\hline 13 & Susanto & 10 & 10 \\
\hline & Tabel III menunjukkan hasil pretest dan
\end{tabular}

posttest peserta pelatihan. Dari hasil tersebut dapat dilihat bahwa sebagian besar peserta (>70\% peserta) mengalami peningkatan kemampuan setelah mengikuti pelatihan ini. Hasil ini diperkuat dengan uji Wilcoxon untuk melihat selisih nilai pretest dan posttest. Hasil uji ini dapat dilihat pada Tabel IV di bawah ini.

TABEL IV HASIL UJI WILCOXON UNTUK SELISIH NILAI PRETEST DAN POSTTEST

\section{Wilcoxon Signed Rank Test: selisih}

Test of median $=0.000000$ versus median $>0.000000$

\begin{tabular}{rrrrrr}
\hline & & $\begin{array}{r}\mathrm{N} \\
\text { for } \\
\text { test }\end{array}$ & $\begin{array}{r}\text { Wilcoxon } \\
\text { Statistics }\end{array}$ & p & $\begin{array}{r}\text { Estim } \\
\text { ated } \\
\text { Medi } \\
\text { an }\end{array}$ \\
\hline Selisih & 13 & 11 & 52.0 & 0.050 & 1.000 \\
\hline
\end{tabular}

Tabel IV menunjukkan hasil uji Wilcoxon untuk selisih nilai pretest dan posttest. Menurut Uji Wilcoxon secara keseluruhan terdapat perbedaan yang signifikan antara pengetahuan sesudah dan sebelum pelatihan. Ini menunjukkan 
pelatihan berjalan efektif. Namun masih ada beberapa peserta yg tidak menunjukkan peningkatan signifikan. beberapa identifikasi penyebab antara lain: (1) Durasi pelatihan yang tidak terlalu lama sehingga peserta tidak dapat menangkap semua materi yang diajarkan; (2) Peserta telah memahami sebagian materi pada saat sebelum dilakukan pelatihan. Setelah itu, dengan adanya pelatihan ini memberikan hal - hal praktis yang dapat membantu mereka untuk implementasi di lapangan. Dengan demikian, peserta dapat mengerti bagaimana penggunaan smartphone android dan bersosial media untuk mendukung kewirausahaan berbasis Teknologi Informasi. Peserta mendapatkan manfaat secara langsung dalam proses pelatihan ini

\section{SIMPULAN}

Kegiatan pengabdian dalam bentuk kegiatan pelatihan optimalisasi android dan penggunaan platform toko online memberikan dampak yang baik bagi anggota Pusat Pemberdayaan Disabilitas Mitra Sejahtera. Kegiatan pelatihan ini dapat meningkatkan kemampuan peserta pelatihan dalam menggunakan teknologi sebagai berjualan secara online. Hal ini dapat dilihat dari halaman resmi facebook yang telah di buat dan diharapkan dapat dijaga.

Selain itu, kegiatan ini juga memberikan pengetahuan baru kepada para anggota Pusat Pemberdayaan Disabilitas Mitra Sejahtera. Hal ini tentunya memberikan dampak yang positif bagi pengembangan kewirausahaan anggota disabilitas Mitra Sejahtera.

\section{DAFTAR PUSTAKA}

Handayani, P. W., Saputro, J. W., Hidayanto, A. N., \& Budi, I. (2010). Peta Rencana (Roadmap) Riset Enterprise Resource Planning (Erp) Dengan Fokus Riset Pada Usaha Kecil Dan Menengah (UKM) Di Indonesia. Jurnal Sistem Informasi, 6(2), 140 145.

Handika, M. R., Maradona, A. F., \& Darma, G. S. (2018, Mei). Strategi Pemasaran Bisnis Kuliner Menggunakan Influencer Melalui Media Sosial Instagram. Jurnal Manajemen dan Bisnis, 15(2), 192 - 203.

Indika, D. R., \& Jovita, C. (2017, Juni). Media Sosial Instagram Sebagai Sarana Promosi Untuk Meningkatkan Minat Beli Konsumen. Jurnal Bisnis Terapan, 1(1), 25 - 32.

Jauhari, J. (2010, April). Upaya Pengembangan Usaha Kecil dan Menengah (UKM) Dengan Memanfaatkan e-Commerce. Jurnal Sistem Informasi, 2(1), 159 - 168.

Palesangi, M. (2012, October 23). Pemuda Indonesia dan Kewirausahaan Sosial. Seminas Competitive Advantage II .

Purwidiantoro, M. H., S.W., D. F., \& Hadi, W. (2016, Maret). Pengaruh Penggunaan Media Sosial Terhadap Pengembangan Usaha Kecil Menengah. EKA CIDA, 1(1), 30 -39.

Rahmawaty, P., Suwarto, D. H., \& Endarwati, M. L. (2011). Pengembangan Metode Pembelajaran Pendidikan Karakter Melalui Kewirausahaan Sosial 
Patria : Jurnal Pengabdian Kepada Masyarakat

ISSN : 2656-5455 (media online) Vol. 3 | No. 1 Maret 2021

(Socioenterpreneurship). Jurnal

Pendidikan Inovatif, 1(2), 1-15.

Ramadhani, F., \& Arifin, Y. (2013).

Optimalisasi Pemanfaatan Teknologi

Informasi Komunikasi Berbasis E-

Commerce Sebagai Media Pemasaran

Usaha Kecil Menengah Guna

Meningkatkan Daya Saing Dalam

Menghadapi Masyarakat Ekonomi

ASEAN 2015. Economics

Development Analysis Journal, 2(2),

$135-139$.

Utomo, H. (2014). Menumbuhkan Minat

Kewirausahaan Sosial. Among

Makarti, 7(14), 1-14.

Zain, N., Febriantara, S., \& Marsofiyati. (2017, Desember). Sosialisasi

Kewirausahaan dan Pendidikan Anak:

Antara Bisnis online dan Mengasuh di

Era Digital. Jurnal Pemberdayaan

Masyarakat Madani, 1(2), 267 - 279. 